UDC 332; DOI 10.18551/rjoas.2022-01.13

\title{
THE HETEROGENEOUS EFFECT OF FISHERMEN GROUP PARTICIPATION ON HOUSEHOLD INCOME: EVIDENCE FROM SMALL-SCALE FISHERMEN IN EAST JAVA OF INDONESIA
}

\author{
Efani Anthon ${ }^{1 *}$, Manzilati Asfi ${ }^{2}$, Sambah Abu Bakar ${ }^{1}$, Rahman M. Shadiqur ${ }^{3}$ \\ ${ }^{1}$ Faculty of Fisheries and Marine Sciences, University of Brawijaya, Malang, Indonesia \\ ${ }^{2}$ Faculty of Economics and Business, University of Brawijaya, Malang, Indonesia \\ ${ }^{3}$ Department of Tropical Agriculture and International Cooperation, \\ National Pingtung University of Science and Technology, Pingtung, Taiwan \\ *E-mail: anthonefani@ub.ac.id
}

\begin{abstract}
Fishermen groups have an essential role to improve fishermen's welfare. However, little evidence demonstrated the association between fishermen's group participation on fishermen's income. This study aims to estimate the heterogeneous effects of fishermen group participation on the household income of fishermen. Cross-sectional data from 178 respondents were considered from fishermen in Malang and Probolinggo regency. Furthermore, we employ an instrumental variable quantile regression (IVQR) model to estimate the heterogeneous effect of fishermen group participation on the household income of fishermen. Generally, the finding indicated that fishermen group participation has a positive and significant effect on the household income of fishermen. Fishermen who participated in the fishermen group tend to have a higher income than those who did not. The heterogeneous effect revealed that at the lowest level of household income level $\left(20^{\text {th }}\right.$ quantile) the fishermen group participation has the lowest income effect of the fishermen. However, the income effect of fishermen group participation is higher in the $40^{\text {th }}, 60^{\text {th }}$, and $80^{\text {th }}$ quantile income. Therefore, we suggested that the fishermen's group participation should be promoted to improve the welfare condition of fishermen.
\end{abstract}

\section{KEY WORDS}

Fishermen group, IVQR, income, East Java, welfare.

Small-scale fishermen who live in the coastal community are usually associated with low-income levels and poverty (Béné and Friend, 2011). This is because small-scale fishermen only depend on marine resources as the primary source of their income with higher risk and uncertainty. Currently, marine resources face several threaten such as climate change, and overfishing, which make small-scale fishermen more vulnerable (Badjeck et al., 2010; Rahman et al., 2021; Shaffril et al., 2017). In addition, limited access to fisheries-related information and technology innovation impacted their resilience (Galappaththi et al., 2019). For instance, in determining the fishing ground location they depend on traditional knowledge (i.e. look into the boiling of fish, and environmental conditions). On the other hand, fishermen also depend on the middleman to sell their catchability due to limited access to the fisheries market (Fahrun et al., 2021; Thủy et al., 2019; Widiastutia and Kusumajantib). As a result, they are unable to achieve the maximum income in fishing activity. To date, the COVID-19 pandemic becoming a new problem in fisheries sectors especially to improve the small-scale fishermen (Hamzah and Nurdin, 2021). During the COVID-19 pandemic, fishermen tend to face difficulty to get what they need, such as fisheries input (labor and fuel) and fisheries market. To improve the fisheriesrelated (information innovation and fisheries market), there is a need for fisheries-related institutions to solve this problem, such as the fishermen group ( $\mathrm{Vu}$ et al., 2020). The fishermen group plays an essential role in reducing poverty, improving food security, and generating income among small-scale fishermen in the coastal area. According to Rahman (2021) fishermen groups are able to improve fishermen's welfare by providing technology innovation and access to the fisheries market. 
Several studies have examined the role of fishermen groups on the socio-economic condition of fisheries sectors. For instance, a study conducted by Rahman (2021) found that fishermen group participation has a positive and significant effect on fishing income and poverty reduction. Furthermore, Abdul-Rahaman and Abdulai (2018) estimated the effect of the farmers' group (which has the same role as the fishermen group in fisheries sectors) on agricultural production and technical efficiency in Ghana. Using propensity score matching and endogenous switching regression approach, they find that participation in farmers' groups has a positive and significant effect on the production and technical efficiency of farmers. Vu et al. (2020) investigated the impact of farmers' groups on household income in Vietnam. The finding revealed that participation in farmers' group participation enables farmers to improve their household income significantly.

Although previous studies have investigated the effect of fishermen groups on the welfare condition of fishermen. But those studies have been done before the COVID-19 pandemic. There is a lack of literature to provide evidence regarding the impact of fishermen groups on the welfare condition of fishermen during the COVID-19 pandemics. Therefore, to fill the gaps, this study examines the income effect of fishermen group participation on small-scale fishermen during the COVID-19 pandemics.

\section{METHODS OF RESEARCH}

This study was conducted in the East Java Province of Indonesia; including Malang regency and Probolinggo regency by considering those two regencies have higher fishing villages and the fishermen under the poverty condition. The data was collected from 178 small-scale fishermen by face-to-face interviews. The structured questionnaire was used during the interview which contains socio-demographic characteristics (such as age, education, number of family members, and fishing experience), fishing activity (i.e. input, production, and sales), social capital (i.e. fishermen group participation), and household income. The household income was determined by the sum of fishing income and off-fishing income that earned by the household.

To estimate the effect of fishermen group participation on the household income of fishermen, this study employed an instrumental variable quantile regression (IVQR) analysis. By this analysis, we can estimate the heterogeneous effect of fishermen group participation by grouping the fishermen by their income quantile. Specifically, followed $\mathrm{Ma}$ and Zheng (2021) the IVQR can be formulated as follows:

$$
\ln \left(I_{i}\right)=q\left(g, x^{\prime}, u\right)=a_{t} g+\beta_{\tau} x^{\prime}+e
$$

Where: $I_{i}$ is the household income of fishermen, $g$ is an endogenous variable of fishermen group participation which measured by dummy variable ( 1 if the fishermen participate in fishermen group, and 0 otherwise), $x$ is a vector of the exogenous variable or the control variables (i.e. age, education, number of family, fishing experience, and off-farm job), $e$ is the error terms. Furthermore $q($.$) Is a function of conditional \tau$ - quantile. $e$ and $\beta$ represent parameters to be calculated at the household income quantile. In addition, in estimating the IVQR, we need at least one instrumental variable that is expected to have a significant correlation with the treatment variable (i.e. farmers group), but it is not significantly affect the outcome variable (household income. in this study, we used neighbor relative membership on the fishermen group and it is measured as a dichotomous variable ( 1 if the neighbor participated in fishermen group and 0 otherwise).

\section{RESULTS AND DISCUSSION}

This section discusses the descriptive statistic of selected variables in this study. The result was presented in table 1 . Our variable is divided into three categories including the treatment variable, Instrumental variable, control variable, and outcome variable. 
Table 1 - Descriptive statistic of variables used in this study

\begin{tabular}{llc}
\hline Variable & Measurement & Mean \\
\hline $\begin{array}{l}\text { Treatment variable } \\
\text { Fishermen group } \\
\text { Instrumental Variable }\end{array}$ & Dummy 1 if the fishermen participate in fishermen group; 0 otherwise & 0.456 \\
$\begin{array}{l}\text { Neighbor participation } \\
\text { Control variables }\end{array}$ & Dummy 1 if the fishermen's neighbor participate in the fishermen group; 0 otherwise & 0.893 \\
Age & Age of the fishermen (Years) & 0.310 \\
Education & Education level of fishermen (Years) & 46.433 \\
Fishing Experience & Fishing experience of fishermen (Years) & 10.413 \\
Off-farm job & Dummy 1 if fishermen have an off-farm job; 0 otherwise & 2.694 \\
Fish aggregating Device & Dummy 1 if the fishermen have fish aggregating device; 0 otherwise & 10.362 \\
$\begin{array}{l}\text { Family Members } \\
\text { Outcome variable }\end{array}$ & Number of family members (person) & 0.343 \\
Household income & Total of household income (Rupiah per month) & 5.232 \\
\hline
\end{tabular}

Firstly, our control variable is fishermen group participation which is measured by a dummy. The average value of the fishermen group variable is about 0.292 , suggesting that $29.2 \%$ of our respondents have participated in the fishermen group, and $70.8 \%$ of our respondents did not participate in the fishermen group. However, the neighbor participation in the fishermen group is relatively high with an average value is 0.893 , suggesting that $89.3 \%$ of the respondent of this study reported their neighbors have participated in the fishermen group. the average age of our respondent is about 46.43 years old with an education level is about 7.16 years, and it reveals that the respondent only graduated from elementary school. The mean value of fishing experience is about 23.03 years, and the minorities of our samples (12.5\%) have an off-farm job. In their fishing activity, an average of the fishermen has fish aggregating device ( 2 units per respondent). The average number of family members of our samples is about 2-4 persons per-household with an average household income is about Rp. 6.141.758 per-month.

The effect of fishermen group participation on the household income of fishermen was presented in table 2. Generally, the fishermen group participation has a positive and significant effect on the household income of fishermen. the finding suggested that fishermen who participated in the fishermen group tend to have a higher income than the fishermen who did not participate in the fishermen group. This is because fishermen groups provide many kinds of benefits, such as technology innovation, access to fisheries-related markets (input or output), and improve fishermen's relation with fisheries-related institutions, government, and industry. However, the income effect of the fishermen group is heterogeneous among the fishermen. in this study, we provide the heterogeneous effect of fishermen group participation based on household income quantile. The result indicated that the income effect of fishermen group participation was lower in the lowest income quantile (20th income quantile). However, the effect was greater in the highest income level $\left(40^{\text {th }}\right.$, $60^{\text {th }}$, and $80^{\text {th }}$ quantiles). This is because fishermen in the lowest level of income usually have little intensity in the fishermen group activity. Hence, they tend to have smaller benefits from the fishermen group relative to the fishermen who have higher intensity in the fishermen group participation. This finding is in line with a previous study conducted by Rahman (2021) who estimated the impact of fishermen group participation on fishermen's welfare conditions. They found that the fishermen group improves the fishermen's welfare condition by improving the fishing income and reducing the poverty condition. Similarly, Abdul-Rahaman and Abdulai (2018), investigated the impact of the agriculture-related group on technical efficiency. They confirmed the positive association between group participation and technical efficiency.

Furthermore, we also provide the influence of the control variables on household income. the result indicated that age, education, and fish aggregating devices have a positive and significant effect on household income. However off-farm job shows a negative and significant influence on household income.

Age has a positive and significant effect on household income at all quantile levels except at the $80^{\text {th }}$ quantile. The finding implies that the older fishermen tend to have a higher income than the youngest fishermen. the older fishermen usually have higher experience in earning income than the youngest ones. Education has a positive and significant effect on 
household income. More educated fishermen are most likely to have higher household incomes than the less educated. This finding is not surprising, because education has an essential role to earn the highest income. By higher education fishermen can make better decision to make a decision. Zhu et al. (2020) report the same finding. They highlight the positive influence of education on income in rural areas. Off-farm job reveals a negative and significant effect on the household income of fishermen. Fishermen who participated in offfarm jobs have lower incomes than those who had not.

Table 2 - The empirical result from the IVQR

\begin{tabular}{|c|c|c|c|c|c|c|c|c|}
\hline \multirow{2}{*}{ Variables } & \multicolumn{8}{|c|}{ Selected quantiles (dependent variable $=$ household income) } \\
\hline & 20th & & 40th & & 60th & & 80th & \\
\hline Fishermen group & 1.258 & $(0.758)^{*}$ & 0.819 & $(0.350)^{\star *}$ & 0.768 & $(0.375)^{\star \star}$ & 0.704 & $(0.354)^{\star \star}$ \\
\hline Age & 0.028 & $(0.015)^{*}$ & 0.026 & $(0.012)^{* *}$ & 0.014 & $(0.011)$ & 0.002 & $(0.010)$ \\
\hline Education & 0.083 & $(0.048)^{*}$ & 0.139 & $(0.038)^{* * *}$ & 0.125 & $(0.037)^{\star * *}$ & 0.078 & $(0.069)$ \\
\hline Fishing Experience & -0.005 & $(0.018)$ & -0.007 & $(0.012)$ & -0.009 & $(0.010)$ & 0.003 & $(0.013)$ \\
\hline Off-farm job & -2.160 & $(0.674)^{\star * *}$ & -1.771 & $(0.593)^{* * *}$ & -1.380 & $(0.443)^{\star * *}$ & -1.374 & $(0.319)^{* * *}$ \\
\hline Fish aggregating Device & 0.096 & $(0.020)^{\star \star \star}$ & 0.107 & $(0.014)^{* * *}$ & 0.091 & $(0.011)^{\star * *}$ & 0.072 & $(0.012)^{* * *}$ \\
\hline Family Members & -0.030 & $(0.126)$ & -0.030 & $(0.083)$ & -0.055 & $(0.096)$ & -0.022 & $(0.119)$ \\
\hline Cons. & 11.568 & $(1.255)$ & 12.100 & $(0.880)$ & 13.584 & $(0.944)$ & 14.755 & $(0.870)$ \\
\hline Sample size & 178 & & 178 & & 178 & & & \\
\hline
\end{tabular}

Note: * **, *** denote significance on $10 \%, 5 \%$, and $1 \%$ respectively.

Although the off-farm job provides income diversification, the fishermen need to reduce their intensity on the fishing activity as the main resource of their income, and they have better specialization on fishing activity than other activities. Therefore, when fishermen are more likely to participate in an off-farm job than the main job, it could negatively affect their income. Lastly, the fish aggregating device has a positive and significant effect on fishermen's income. Fishermen who own a higher number of fish aggregating devices tend to have higher incomes. The fish aggregating device is a fishing tool that helps fishermen to attract fish when they are fishing. By the fish aggregating device fishermen are more likely to get the highest catchability that can improve their income.

\section{CONCLUSION}

This study investigated the income effect of fishermen group participation on smallscale fishermen households. The study was conducted in the East Java Province of Indonesia during the COVID-19 pandemics. Using cross-sectional data from 178 fishermen's households, this study employed an instrumental quantile regression (IVQR). We found the fishermen group participation has an important role to improve the household income of fishermen during the covid-19 pandemics. The heterogeneous analysis revealed that at the lowest level of household income level $\left(20^{\text {th }}\right.$ quantile) the fishermen group participation has the lowest income effect of the fishermen. However, the income effect of fishermen group participation is higher in the $40^{\text {th }}, 60^{\text {th }}$, and $80^{\text {th }}$ quantile income. In addition, the fishermen group is significantly affected by age, education, off-farm job, and fish aggregating device. Based on the finding of this study, we suggest the improvement of fishermen group participation continuously through fishermen to fishermen extension, extension agent, and fisheries-related institution.

\section{REFERENCES}

1. Abdul-Rahaman A and Abdulai A. (2018) Do farmer groups impact on farm yield and efficiency of smallholder farmers? Evidence from rice farmers in northern Ghana. Food policy 81: 95-105.

2. Badjeck M-C, Allison EH, Halls AS, et al. (2010) Impacts of climate variability and change on fishery-based livelihoods. Marine Policy 34: 375-383.

3. Béné $C$ and Friend RM. (2011) Poverty in small-scale fisheries: old issue, new analysis. Progress in Development Studies 11: 119-144. 
4. Fahrun M, Dirwan D and Rajindra R. (2021) Study on the Poverty of Traditional Fishermen in Lombonga Village, Balaesang District, Donggala Regency. International Journal of Health, Economics, and Social Sciences (IJHESS) 3: 156-164.

5. Galappaththi EK, Ford JD, Bennett EM, et al. (2019) Climate change and community fisheries in the arctic: a case study from Pangnirtung, Canada. Journal of environmental management 250: 109534.

6. Hamzah A and Nurdin H. (2021) Economic Resilience of Fishermen Community During Covid-19 Pandemic. IOP Conference Series: Earth and Environmental Science. IOP Publishing, 012062.

7. Ma W and Zheng H. (2021) Heterogeneous impacts of information technology adoption on pesticide and fertiliser expenditures: Evidence from wheat farmers in China. Australian Journal of Agricultural and Resource Economics.

8. Rahman M, Toiba $\mathrm{H}$ and Huang W-C. (2021) The impact of climate change adaptation strategies on income and food security: Empirical evidence from small-scale fishers in Indonesia. Sustainability 13: 7905.

9. Rahman MSH, Wen-Chi (2021) The welfare effect of fishermen group participation on smallholder fishermen in East Java of Indonesia. 2021 International Wetland Convention in Taiwan. Taipe.

10. Shaffril HAM, Samah AA and D'Silva JL. (2017) Adapting towards climate change impacts: Strategies for small-scale fishermen in Malaysia. Marine Policy 81: 196-201.

11. Thủy PTT, Flaaten $O$ and Skonhoft A. (2019) Middlemen: good for resources and fishermen? Environment and Development Economics 24: 437-456.

12. Vu HV, Ho H and Le QH. (2020) Impact of Farmers' Associations on Household Income: Evidence from Tea Farms in Vietnam. Economies 8: 92.

13. Widiastutia NPE and Kusumajantib AK. How Does Local Government Strategy Empower Traditional Fishermen (A Case Study in Java Island-Indonesia).

14. Zhu Z, Ma W and Leng C. (2020) ICT adoption, individual income and psychological health of rural farmers in China. Applied Research in Quality of Life: 1-21. 